Prepared in cooperation with the Sokaogon Chippewa Community and Indian Health Service

\title{
Simulation of the Shallow Groundwater-Flow System near Mole Lake, Forest County, Wisconsin
}

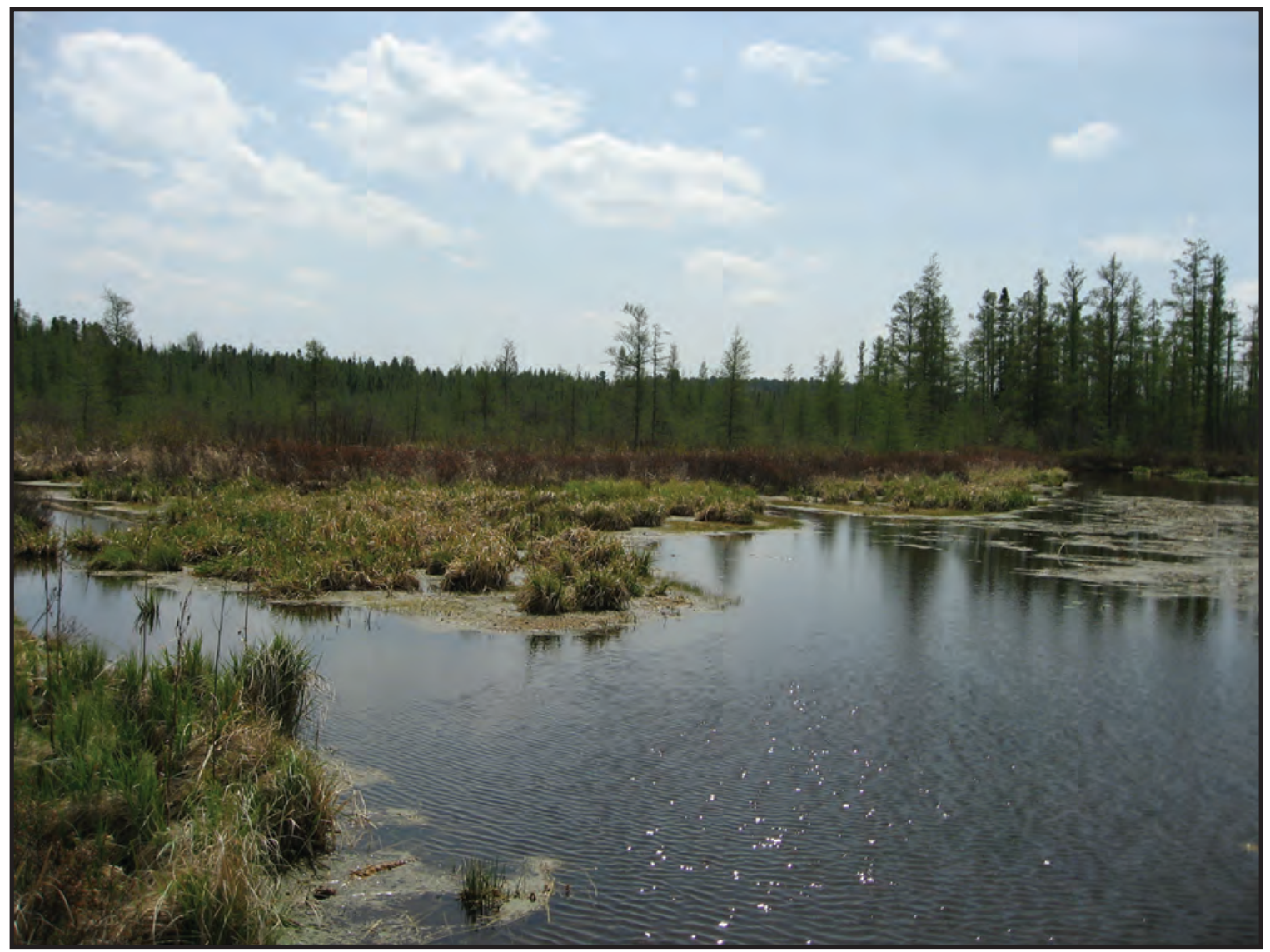

Scientific Investigations Report 2011-5080
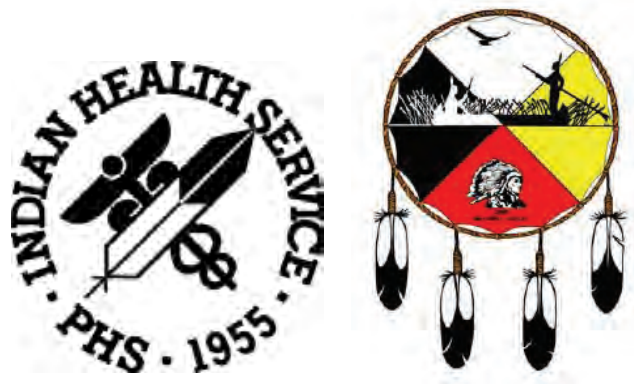
Cover. Rice Lake, Forest County, Wisconsin. (Photograph by Michael N. Fienen, U.S. Geological Survey.) 


\section{Simulation of the Shallow Groundwater- Flow System near Mole Lake, Forest County, Wisconsin}

By Michael N. Fienen, Paul F. Juckem, and Randall J. Hunt

Prepared in cooperation with the Sokaogon Chippewa Community and Indian Health Service

Scientific Investigations Report 2011-5080

U.S. Department of the Interior

U.S. Geological Survey 


\section{U.S. Department of the Interior \\ KEN SALAZAR, Secretary \\ U.S. Geological Survey \\ Marcia K. McNutt, Director}

\section{U.S. Geological Survey, Reston, Virginia: 2011}

For more information on the USGS - the Federal source for science about the Earth, its natural and living resources, natural hazards, and the environment, visit http://www.usgs.gov or call 1-888-ASK-USGS.

For an overview of USGS information products, including maps, imagery, and publications, visit http://www.usgs.gov/pubprod

To order this and other USGS information products, visit http://store.usgs.gov

Any use of trade, product, or firm names is for descriptive purposes only and does not imply endorsement by the U.S. Government.

Although this report is in the public domain, permission must be secured from the individual copyright owners to reproduce any copyrighted materials contained within this report.

Suggested citation:

Fienen, M.N., Juckem, P.F., and Hunt, R.J., 2011, Simulation of the shallow groundwater-flow system near Mole Lake,

Forest County, Wisconsin: U.S. Geological Survey Scientific Investigations Report 2011-5080, 9 p. 


\section{Acknowledgments}

The authors thank Matt Zoch of the Indian Health Services for originating and supporting this study and Roman Ferdinand and Dori McGeshick of the Sokaogon Chippewa Community for field support. Reviews by David Saad and Christopher Hoard of the U.S. Geological Survey are also appreciated and their comments improved this manuscript. 


\section{Contents}

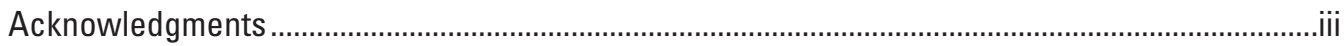

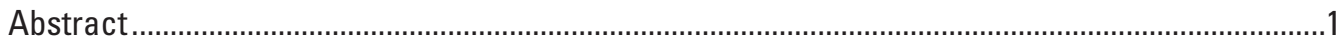

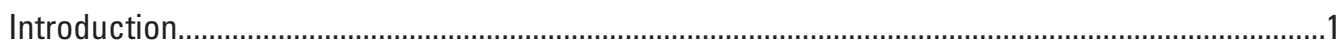

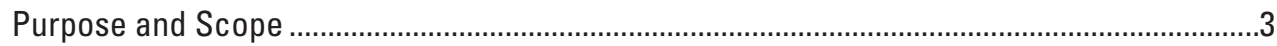

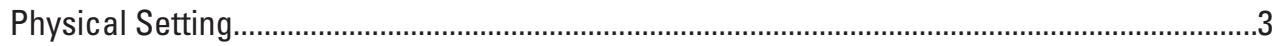

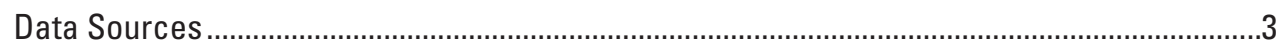

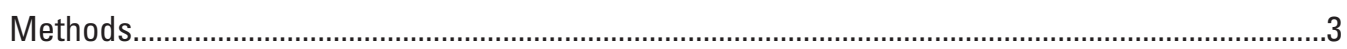

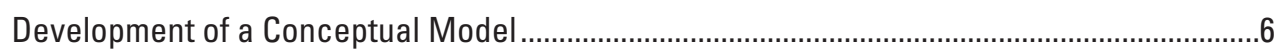

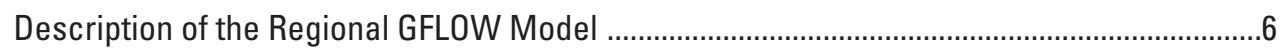

Refinement of the Regional Model near Mole Lake ........................................................7

Application of the Model to Simulate Areas Contributing Recharge to Existing and

Proposed Wells near Mole Lake...............................................................................................

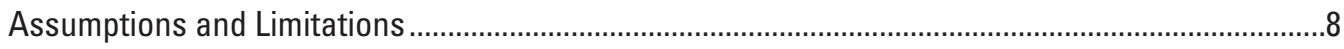

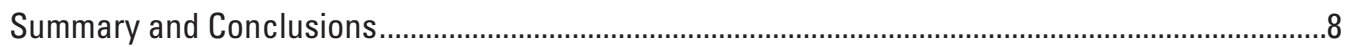

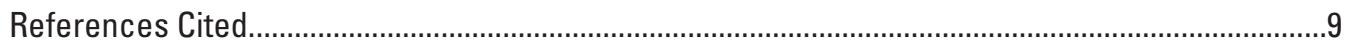

\section{Figures}

1. Map showing study area location near Mole Lake, Forest County, Wisconsin, and overview of major model elements (modified from Kelson and others, 2002) ............2

2. Map showing simulated areas contributing recharge using the GFLOW model assuming the base scenario of three wells pumping 32 gallons per minute...................... 4

3. Map showing simulated areas contributing recharge using the GFLOW model simulating the high pumping scenario of three wells pumping 70 gallons per minute.....5 


\section{Conversion Factors and Abbreviations, Datums, and Abbreviated Water-Quality Units}

\begin{tabular}{|c|c|c|}
\hline Multiply & By & To obtain \\
\hline \multicolumn{3}{|c|}{ Length } \\
\hline inch (in) & 2.54 & centimeter $(\mathrm{cm})$ \\
\hline foot (ft) & 0.3048 & meter (m) \\
\hline mile (mi) & 1.609 & kilometer (km) \\
\hline \multicolumn{3}{|c|}{ Area } \\
\hline square mile $\left(\mathrm{mi}^{2}\right)$ & 259.0 & hectare (ha) \\
\hline \multicolumn{3}{|c|}{ Volume } \\
\hline gallon (gal) & 3.785 & liter (L) \\
\hline \multicolumn{3}{|c|}{ Flow rate } \\
\hline cubic foot per day (ft³/d) & 0.02832 & cubic meter per day (m³/d) \\
\hline gallon per minute (gal/min) & 0.06309 & liter per second (L/s) \\
\hline gallon per day (gal/d) & 0.003785 & cubic meter per day $\left(\mathrm{m}^{3} / \mathrm{d}\right)$ \\
\hline inch per year (in/yr) & 25.4 & millimeter per year (mm/yr) \\
\hline \multicolumn{3}{|c|}{ Hydraulic conductivity* } \\
\hline foot per day (ft/d) & 0.3048 & meter per day $(\mathrm{m} / \mathrm{d})$ \\
\hline
\end{tabular}

Vertical coordinate information is referenced to the North American Vertical Datum of 1988 (NAVD 88).

Horizontal coordinate information is referenced to the North American Datums of 1983 and 1997 (NAD 83, 97).

Elevation, as used in this report, refers to distance above the vertical datum.

*Hydraulic conductivity: The standard unit for hydraulic conductivity is cubic foot per day per square foot of aquifer cross-sectional area $\left(\mathrm{ft}^{3} / \mathrm{d} / \mathrm{ft}^{2}\right)$. In this report, the mathematically reduced form, foot per day (ft/d), is used for convenience. 



\title{
Simulation of the Shallow Groundwater-Flow System near Mole Lake, Forest County, Wisconsin
}

\author{
By Michael N. Fienen, Paul F. Juckem, and Randall J. Hunt
}

\section{Abstract}

The shallow groundwater system near Mole Lake, Forest County, Wis. was simulated using a previously calibrated regional model. The previous model was updated using newly collected water-level measurements and refinements to surface-water features. The updated model was then used to calculate the area contributing recharge for one existing and two proposed pumping locations on lands of the Sokaogon Chippewa Community.

Delineated 1-, 5-, and 10-year areas contributing recharge for existing and proposed wells extend from the areas of pumping to the northeast of the pumping locations. Steadystate pumping was simulated for two scenarios: a base pumping scenario using pumping rates that reflect what the Tribe expects to pump and a high pumping scenario, in which the rate was set to the maximum expected from wells installed in this area. In the base pumping scenario, pumping rates of 32 gallons per minute (gal/min; 46,000 gallons per day (gal/d)) from the existing well and $30 \mathrm{gal} / \mathrm{min}(43,000 \mathrm{gal} / \mathrm{d})$ at each of the two proposed wells were simulated. The high pumping scenario simulated a rate of $70 \mathrm{gal} / \mathrm{min}(101,000 \mathrm{gal} / \mathrm{d})$ from each of the three pumping wells to estimate of the largest areas contributing recharge that might be expected given what is currently known about the shallow groundwater system. The areas contributing recharge for both the base and high pumping scenarios did not intersect any modeled surface-water bodies; however, the high pumping scenario had a larger areal extent than the base pumping scenario and intersected a septic separator.

\section{Introduction}

A new groundwater-pumping regime has been proposed by the Sokaogon Chippewa Community (SCC) that includes ongoing pumping from an existing well with additional pumping from two proposed wells on the Mole Lake Indian
Reservation near the village of Mole Lake, Forest County, Wis. (fig. 1). A study was performed by the U.S. Geological Survey (USGS), in cooperation with the SCC and Indian Health Services, to delineate the area contributing recharge to each of the three wells in the proposed pumping regime. The area contributing recharge is the two-dimensional projection, or footprint on the land surface, of the water entering the aquifer system that will be captured by a well. Contributing recharge areas are useful for identifying the parts of the aquifer system encountered by water entering wells and have utility for assessing a well's vulnerability to contamination.

The village of Mole Lake and the proposed wells reside in an area encompassed by a previously published model of the regional shallow groundwater system (Kelson and others, 2002) (fig. 1). To improve understanding of shallow groundwater flow in the local Mole Lake area, additional field data collection, model refinement, and model simulations were completed by the USGS, in cooperation with the SCC. The locally refined model was then used to evaluate areas contributing recharge to wells under an expected pumping regime (base pumping scenario) and a maximum expected pumping scenario (high pumping scenario).

Previously published values of horizontal hydraulic conductivity used in the updated model included $32.8 \mathrm{ft} / \mathrm{d}$ for the regional glacial and sandstone aquifers and 10.8 and $19.4 \mathrm{ft} / \mathrm{d}$ for two local inhomogeneity inclusions located to the east of the site area (fig. 1). These values are listed under "Q80 without Lake Lucerne" in table 1 of Kelson and others (2002). Groundwater recharge in the calibrated regional model was $7.2 \mathrm{in} / \mathrm{yr}$. The recharge and hydraulic conductivity values chosen for the updated model reflected low recharge and low streamflow conditions. In a simple aquifer system, the ultimate source of water to a well is recharge to the water table and the size of a well's area contributing recharge is inversely related to the recharge rate for a given pumping rate (Reilly and Pollock, 1993). In this relatively simple aquifer system, low recharge conditions represent the largest expected areas of contribution, thus forming a conservative endmember of well vulnerability. 


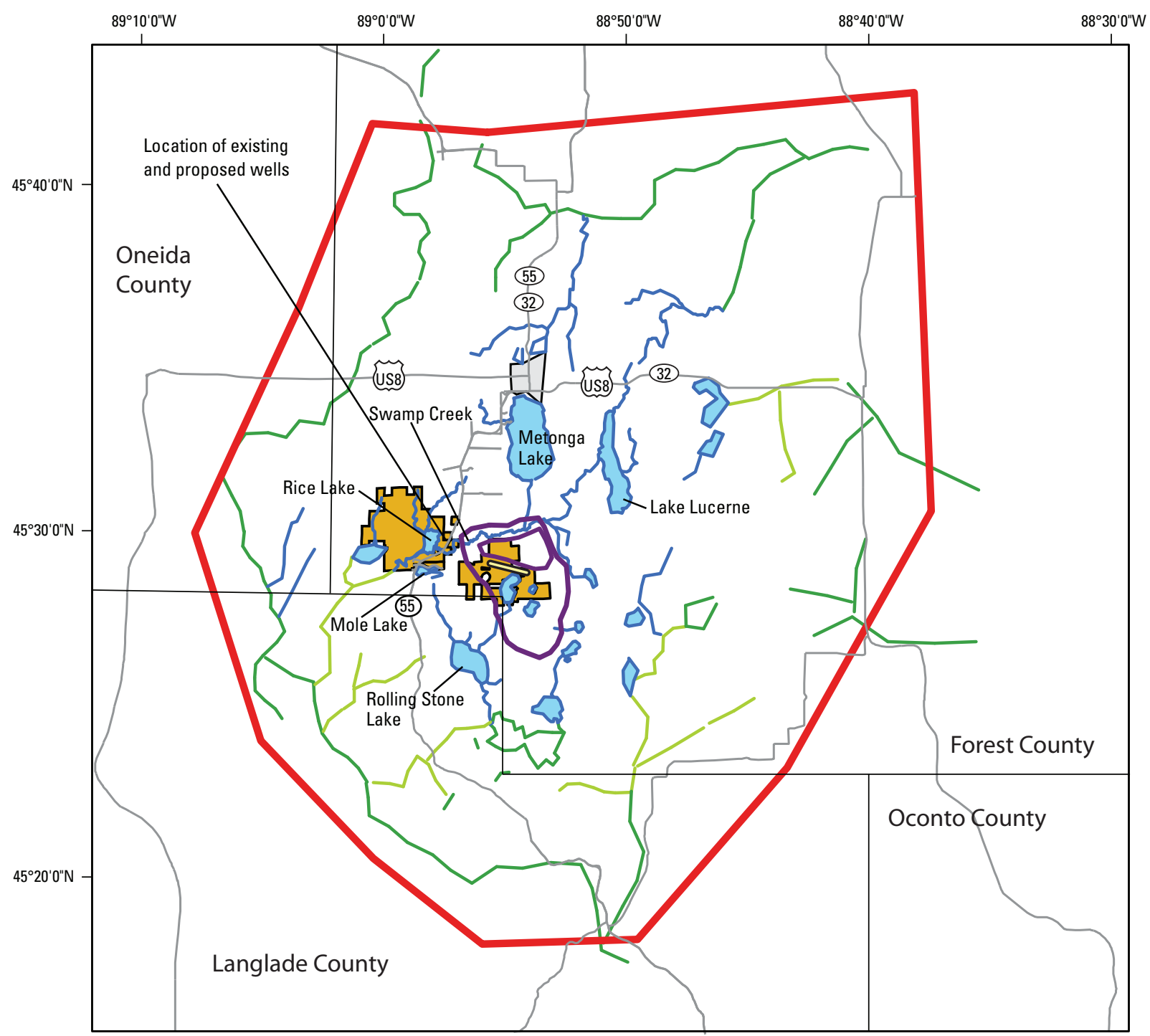

Base map compiled and modified from digital data sources:

U.S. Geological Survey, 1:250,000

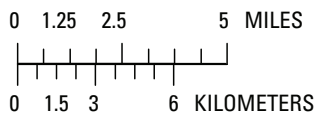

\section{EXPLANATION}

$\square$ Town of Crandon

$\square$ Nearfield analytic elements representing lakes

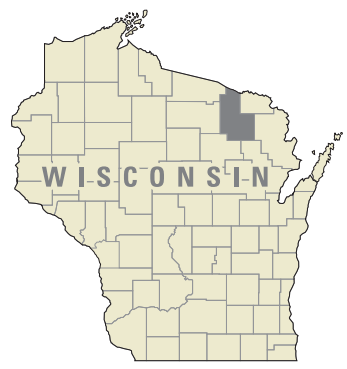

$\square$ Sokaogon Chippewa Community Lands

Nearfield line elements representing routed streams

Nearfield line elements representing nonrouted streams

Farfield analytic elements

Outline of recharge boundary

Approximate location of ore body

Hydraulic conductivity inhomogeneity

Figure 1. Map showing study area location near Mole Lake, Forest County, Wisconsin, and overview of major model elements (modified from Kelson and others, 2002). 


\section{Purpose and Scope}

This report describes changes to the regional groundwater model of Kelson and others (2002) used for simulation of the shallow groundwater-flow system near the community of Mole Lake, Wis. and the surrounding areas. Simulations were performed using the model to delineate the areas contributing recharge to three pumping wells corresponding to two pumping scenarios selected by the SCC. Because of the locations of the wells, an emphasis on groundwater and surface-water interactions, and the absence of confining units in the modeled area the model refinement and new data collection focused on the shallow groundwater-flow system near Rice Lake, Swamp Creek, and the community of Mole Lake.

\section{Physical Setting}

The study area (fig. 1) is located in southwestern Forest County, Wis. Seepage and drainage lakes are common in the area and influence the groundwater-flow system. The two proposed and one existing wells are located near Rice Lake (figs. 2 and 3), and Swamp Creek flows near the site on the east and south into Rice Lake (figs. 1-3). The regional area hydrology is discussed in more detail by Kelson and others (2002). In the 1990s, a mine was proposed in the study area which was the motivation for the Kelson and others (2002) model.

\section{Data Sources}

With the few exceptions noted below, this study is based on the previously published model of Kelson and others (2002). Surface-water elevations for Rice Lake, Swamp Creek, and Mole Lake were specified in the current model using data collected on April 30, 2010, and are more representative of current conditions. The water elevation in Rice Lake was $1,532 \mathrm{ft}$ in the original model but was updated to $1,533.01 \mathrm{ft}$ in the new measurements, and the elevation in Mole Lake was updated from 1,552 to $1,548.33 \mathrm{ft}$. The updated elevation in Swamp Creek was 1,533.53 ft. All surface-water level measurements are reported as feet and are referenced to the North American Vertical Datum of 1988 (NAVD 88). The small change in water level in Rice Lake further indicates that the calibrated parameters from the original model are applicable. Although the change in Mole Lake is greater, the influence of this lake is buffered by the location of Swamp
Creek. The locations of existing and proposed groundwater wells, and a nearby septic separator, were determined during this field investigation. The septic separator is an installation at which solid and liquid wastes are separated in sewage prior to ultimate discharge. This differs from a leach field in that waste does not typically infiltrate here, although if a leak to the water table were to occur, intersection with the area contributing recharge would be important to consider in management.

\section{Methods}

The two-dimensional model used for this study is an analytic element groundwater-flow model (GFLOW, Haitjema, 1995) that was previously developed for the region by Kelson and others (2002). Hunt (2006) gives a review of applications of the analytic element method, and Haitjema (1995) discusses the underlying concepts and mathematics of the method in detail. A complete description of analytic elements is beyond the scope of this report, but a brief description follows.

An infinite aquifer is assumed in analytic element modeling. The problem domain (model area) does not require a grid or involve interpolation between cells. To construct an analytic element model, features important for controlling groundwater flow (for example, wells and surface-water features) are entered as mathematical elements or strings of elements. The amount of detail specified for the features depends on distance from the area of interest. Each element is represented by an analytic solution to the groundwater flow equation. The effects of these individual solutions are added together to form a solution for any location in the simulated groundwater-flow system. Because the solution is not confined to a grid, heads and flows can be computed anywhere in the model domain without nodal averaging. In the GFLOW model used here, the analytic elements are two dimensional and are used only to simulate steady-state conditions - that is, water levels and streamflows that do not vary with time. The analytic element method and comparisons of analytic element to finite-difference numerical model techniques have been discussed by others (Haitjema, 1995; Hunt and Krohelski, 1996; Hunt and others 1998; Hunt and others, 2003; and Hunt, 2006).

The regional GFLOW model of Kelson and others (2002) was calibrated with the parameter estimation code UCODE (Poeter and Hill, 1998). Details about the calibration and data are provided in Kelson and others (2002). 


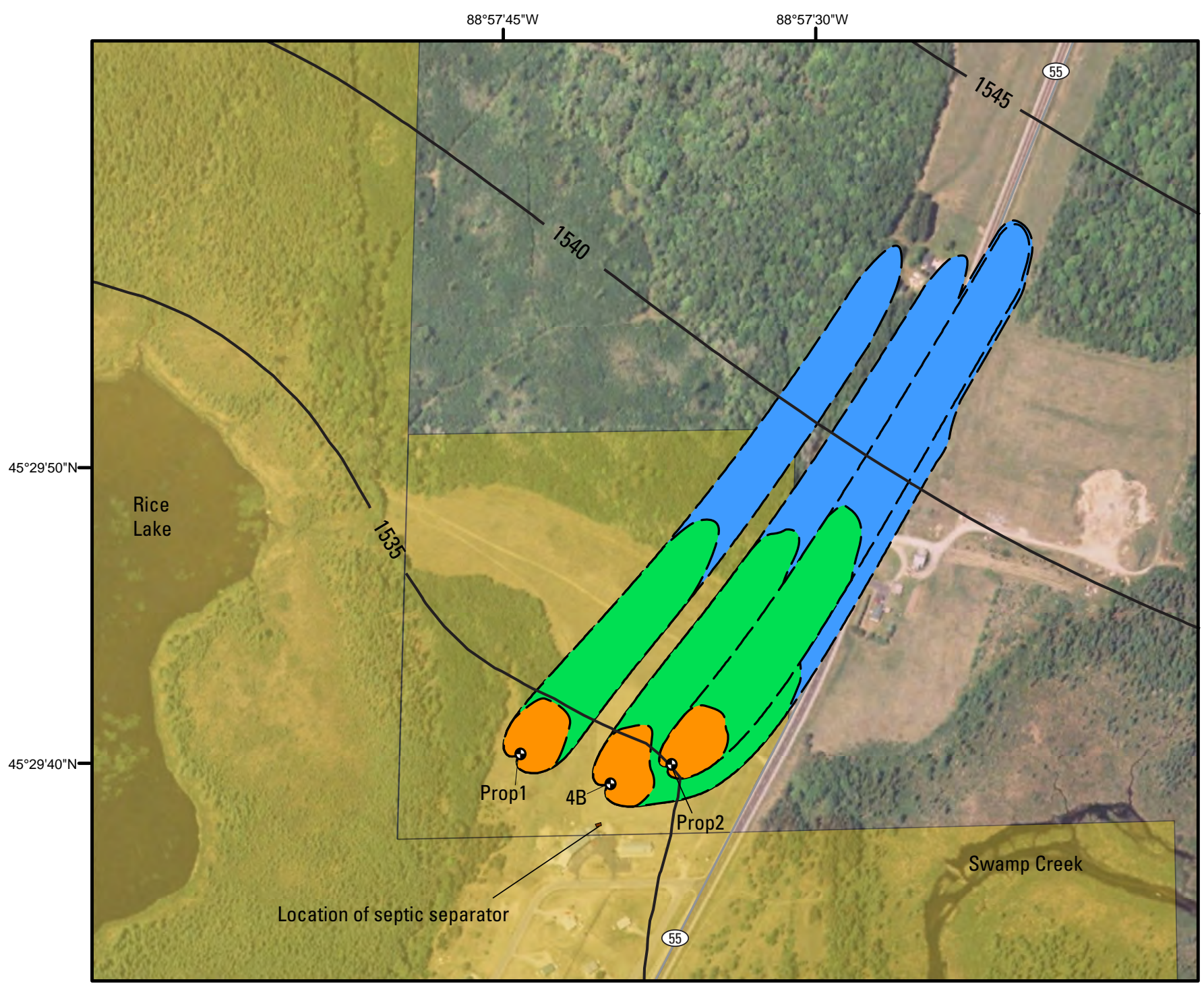

Base map compiled and modified from digital data sources: U.S. Department of Agriculture (2006)

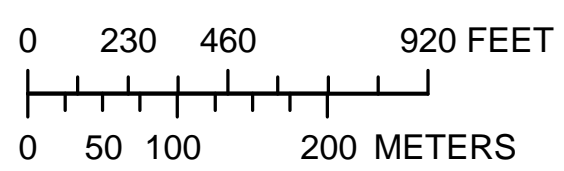

\section{EXPLANATION}

Sokaogon Chippewa Community Lands

1-year area contributing recharge

5-year area contributing recharge

10-year area contributing recharge

Piezometric head contours (numbers indicate feet MSLD)

- Bounding streamlines delineating zones of contributing recharge

- Proposed or existing pumping well

Figure 2. Map showing simulated areas contributing recharge using the GFLOW model assuming the base scenario of three wells pumping 32 gallons per minute. 


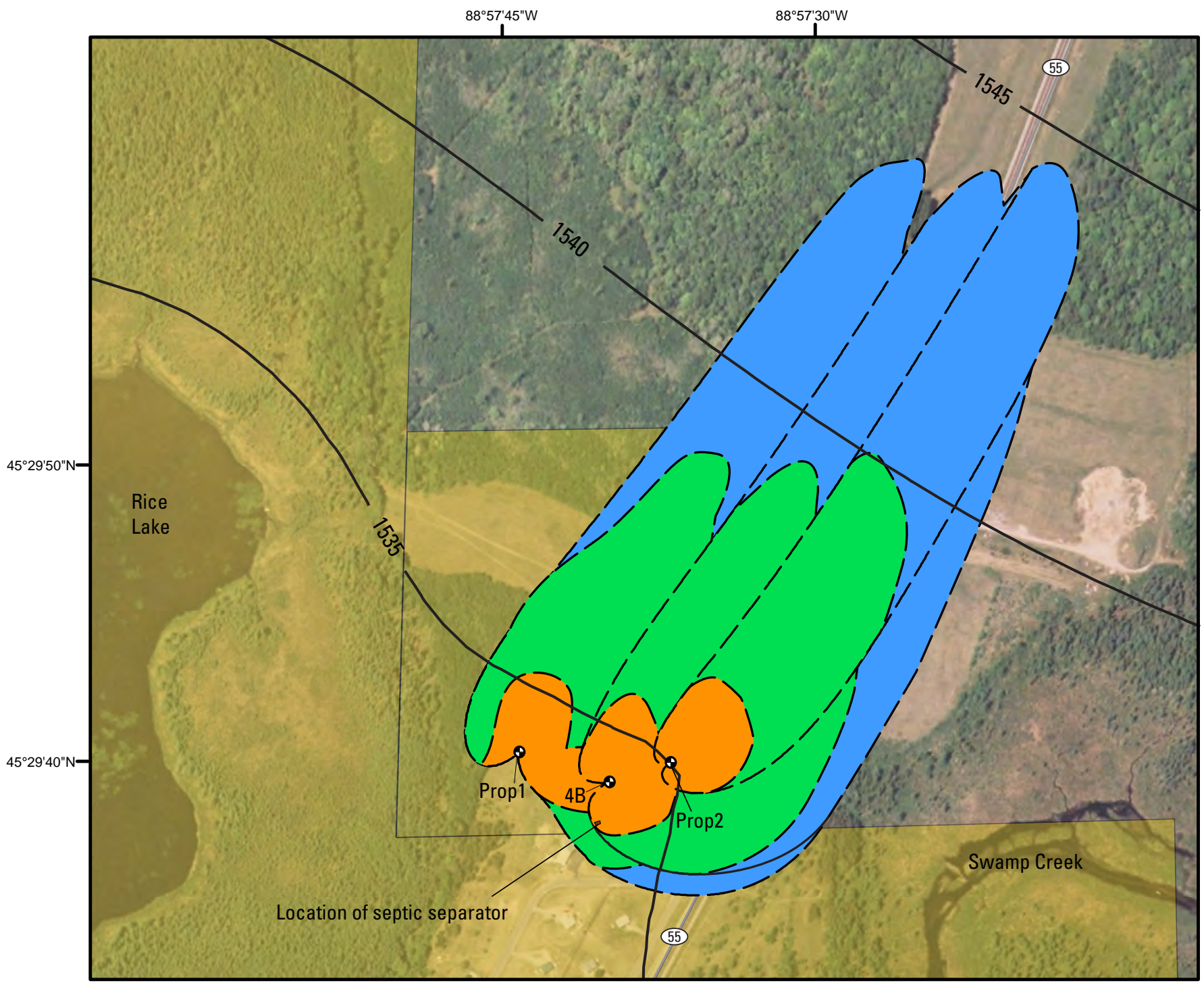

Base map compiled and modified from digital data sources: U.S. Department of Agriculture (2006)

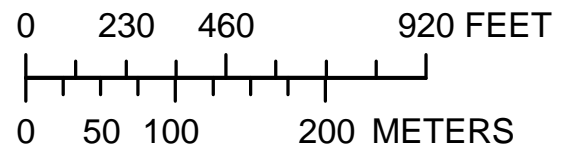

\section{EXPLANATION}

Sokaogon Chippewa Community Lands

1-year area contributing recharge

5-year area contributing recharge

10-year area contributing recharge

Piezometric head contours (numbers indicate feet MSLD)

- - Bounding streamlines delineating zones of contributing recharge

- Proposed or existing pumping well

Figure 3. Map showing simulated areas contributing recharge using the GFLOW model simulating the high pumping scenario of three wells pumping 70 gallons per minute. 


\section{Development of a Conceptual Model}

Before simulating the groundwater system using a flowmodeling code, a conceptualization of the hydrologic system is essential because it forms the framework for model development and reduces the groundwater system into important component parts. This reduction is a necessary simplification of the hydrologic system because inclusion of all of the complexities into a model is not feasible. Steps in the development of the conceptual model include: (1) characterization of the aquifer(s); (2) identification of sources and sinks of water; and (3) identification and delineation of hydrologic features in the area of interest.

The regional groundwater system in the Mole Lake area is a relatively thin (ranging from about 15 to $150 \mathrm{ft}$ in thickness) glacial aquifer overlying comparatively impermeable Precambrian igneous and metamorphic rocks (Soller and Packard, 1998). Groundwater moves from higher to lower hydraulic potential (areas of higher groundwater levels to areas of lower groundwater levels). As a result, groundwater generally discharges to surface-water features or pumping wells and recharges in areas distributed areally throughout the study area. Accurate locations of surface-water features and pumping wells are, therefore, critical to simulating the local groundwater-flow system in the vicinity of Mole Lake.

\section{Description of the Regional GFLOW Model}

The regional GFLOW model used in this work is described in Kelson and others (2002). The mining site was proposed to target the ore body in the area generally indicated by the hydraulic conductivity inhomogeneities as identified in figure 1 . The $900-\mathrm{mi}^{2}$ regional model, outlined in figure 1 by the recharge-area boundary, encompasses both Mole Lake and Rice Lake and the area of the existing and proposed wells.

Initial model development included estimating the elevation of the base of the groundwater system, horizontal hydraulic conductivity, and recharge rate. The base of the model (1,100 ft above NAVD 88) roughly corresponds with the top of the crystalline bedrock near the area of Mole Lake. In twodimensional areal models, where the transmissivity of a single layer represents the flow system, the base elevation is correlated with hydraulic conductivity. Therefore, model calibration focused on horizontal hydraulic conductivity rather than the aquifer base elevation. As a result, aquifer base elevation was held constant and not varied during model calibration. In addition to horizontal hydraulic conductivity, which was assigned three values corresponding to different areas of inhomogeneities identified in figure 1 , groundwater recharge was also considered a calibration parameter; therefore, these parameters were varied during model calibration. These parameters were estimated using calibration targets that included head values in wells and stream discharge at 10 locations at "low-flow" periods, which are referred to as the $\mathrm{Q}_{80}$ flow and are defined as periods when measured flows are above 80 percent of the time, discussed by Kelson and others (2002). The size of areas contributing recharge to wells is approximately inversely related to recharge value: higher values of recharge results in smaller areas contributing recharge for a given pumping rate. Therefore, estimating recharge corresponding to $Q_{80}$ flow conditions results in a lower estimated value of recharge and correspondingly larger areas contributing recharge. This can be considered a conservative estimate of the well's capture, because its larger size provides a larger margin of safety when evaluating potential source areas to the well.

Published values of horizontal hydraulic conductivity values used in the model included $32.8 \mathrm{ft} / \mathrm{d}$ for the regional glacial and sandstone aquifer, and 10.8 and $19.4 \mathrm{ft} / \mathrm{d}$ for two local inhomogeneity inclusions located to the east of Mole Lake (fig. 1). Groundwater recharge in the calibrated regional model was $7.2 \mathrm{in} / \mathrm{yr}$ (Kelson and others, 2002). These values were all estimated assuming $\mathrm{Q}_{80}$ flow conditions.

The groundwater-flow model consists of far-field and near-field elements where the latter reflect the area of interest and are characterized by more sophisticated representation of surface-water features and concentration of field data collection. The geometry of the closest near-field elements to the three wells was refined relative to the Kelson and others (2002) model. These refinements include the channel geometry of Swamp Creek and the shoreline of Rice Lake, and they were based on USGS topographic 7-minute quadrangle data. On the basis of the conceptual model, the location and elevation of far-field surface-water features were included from the Kelson and others (2002) model (fig. 1). These features are rivers and lakes distant from Mole Lake that are simulated with coarse linesink networks and little or no resistance between the surface-water features and the groundwater system. Because an infinite aquifer extent is assumed in the analytic element method, the purpose of simulating the far-field features is to have the model explicitly simulate the general groundwater flow in the region and to buffer the nearfield area of interest from boundary effects. The near-field area is focused around the eastern shore of Rice Lake and north of Swamp Creek where the well field is proposed.

Streambed resistance in the near field was set equal to 0.3 day by Kelson and others (2002). Resistance is defined as the streambed-sediment thickness divided by the vertical hydraulic conductivity. For example, the model value of 0.3 day corresponds to a $1-\mathrm{ft}$ sediment thickness and a vertical hydraulic conductivity of $3 \mathrm{ft} / \mathrm{d}$. Parameter sensitivity assessments (Kelson and others, 2002) demonstrated that the model results were not sensitive to changes in streambed resistance when varied over reasonable ranges; therefore, the values for all streams were fixed in all model runs. The width of each stream was assigned according to stream order and field observations, and it ranged from 10 to $100 \mathrm{ft}$. 
Lakes were simulated using linesinks with resistance and streamflow routing in the near field. Drainage lakes (lakes that have a stream outlet) in the near field were linked to the stream network by stream elements, based on the methods of Hunt and others (1998). Within the perimeter of each lake, the recharge rate applied to the lake represents net precipitation rather than groundwater recharge; therefore, the water added to the lakes differs from that of the regional aquifer. (This can be expressed by the equation Rlake = P-Elake; where Rlake is the net precipitation recharged inside the lake, $P$ is the annual precipitation, and Elake is the evaporation rate from the lake.) The net precipitation recharged inside all near-field lakes in the model was set equal to $2.3 \mathrm{in} / \mathrm{yr}$. The value of lake linesink resistance was set to 0.3 days for all near-field lakes. The width assigned to linesinks representing lakes was half the length of the shortest axis of the lake represented by the linesink. The only pumping simulated in the model was from the existing well (4B) and proposed wells Prop1 and Prop2, identified in figures 2 and 3.

\section{Refinement of the Regional Model near Mole Lake}

The regional groundwater-flow model was locally refined in an effort to more accurately simulate local-scale groundwater flow near the proposed and existing wells in the Mole Lake area. The Swamp Creek channel geometry and the Mole Lake and Rice Lake shorelines were refined by adding detail to the linesinks based on USGS topographic 7-minute quadrangle maps. This refinement includes more detail of their lateral shape and updated water levels in Rice Lake and Mole Lake. These updated water levels were measured on April 30, 2010, as discussed above, using a real-time kinematic (RTK) globalpositioning system (GPS). This RTK-GPS system is capable of providing sub-inch level accuracy, both vertically and horizontally, by differentially correcting GPS signals recorded at two separate GPS receivers (Wolf and Ghilani, 2002). The field survey was referenced to the Universal Transverse Mercator coordinate system and the North American Datums of 1983 and 1997 (horizontal) and NAVD 88 (vertical) datums The water level in Rice Lake increased by $1 \mathrm{ft}$ relative to the original model, while the water level in Mole Lake decreased by $4 \mathrm{ft}$.

\section{Application of the Model to Simulate Areas Contributing Recharge to Existing and Proposed Wells near Mole Lake}

The areal extent of areas contributing recharge to the existing community well (4B) and to two proposed wells (Prop1 and Prop2) were assessed by use of the locally refined model simulations of the Mole Lake area (figs. 2 and 3). The areas contributing recharge to the wells were delineated by backward particle tracking from the well to the area of recharge. Mathematical particles of water were placed within the well at the bottom of the aquifer and traced backwards to the water table using the updated model. By use of a porosity of 0.2 , which is on the lower end of the range typical of sand (Freeze and Cherry, 1979), estimates of the time required for a particle of water in the contributing area to reach the well also were calculated (figs. 2 and 3). Using the lower range porosity value is conservative because it results in larger areas contributing recharge.

The simulated 1-, 5-, and 10-year areas contributing recharge for the base pumping scenario (fig. 2) (pumping rate of $32 \mathrm{gal} / \mathrm{min}$ ) extend to the north and east of the well locations. This is consistent with regional groundwater flow emanating from the northeast in this location (Kelson and others, 2002). The areas contributing recharge do not overlap the location of the septic separator nor do they intersect any surface-water features. In the high pumping scenario (70 gal/min; fig. 3), similar geometry and orientation of the areas contributing recharge are observed. The areas contributing recharge are larger, as expected due to the much higher pumping rates simulated, but they still do not intersect surfacewater features. The edges of the areas contributing recharge are simulated as very near or encompassing the septic separator on their southern edge at these high simulated pumping rates. It should be noted that the simulated areas contributing recharge are for scenarios in which all three wells are pumping at a constant rate. Areas contributing recharge presented, therefore, represent an average condition over time. 


\section{Assumptions and Limitations}

Given the relatively high hydraulic conductivity of the aquifer, relatively high groundwater-recharge rate, and presence of springs and perennial headwater streams, the groundwater and surface-water systems are assumed to be in close hydrologic connection in the study area, and elevations of surface-water features are assumed to be approximate heads in the underlying groundwater system. A two-dimensional groundwater-flow model was assumed to be appropriate for this application because the groundwater-flow system is relatively thin and areally extensive. Steady-state conditions were assumed to be appropriate for this system because hydraulic conductivity is high and distances between surface-water features are relatively small (Kelson and others, 2002); these characteristics help dampen the effects of periodic transient stresses applied to the system (Haitjema, 1995). Steady-state assumptions, which ignore groundwater release from storage, can be expected to result in an estimate of the higher range of system response (such as water level drawdown due to pumping) to a hydrologic stress.

Limitations of the model result from these assumptions. Namely, local three-dimensional flow and transient system response expected near wells and surface-water features are only approximately represented. In addition, local features of the groundwater system (for example, local variations in hydraulic conductivity and recharge) are only approximated by the parameterization used in the regional model of Kelson and others (2002).

The calibration of the model performed by Kelson and others (2002) was not repeated because the refinements to the model were local, focused on the immediate area near the water supply wells. Furthermore, the most important change in water level, in Rice Lake, was only $1 \mathrm{ft}$. The model code has been updated since Kelson and others (2002) performed the initial calibration. When changes to the code, updated water levels (decreased stages in Mole Lake, Rice Lake, and Swamp Creek), and refined model elements near the three wells are considered, the difference in base flow measured where Swamp Creek crosses Highway 55 (the target referred to as "Ground water discharge from Swamp Creek @ 55" in table 1 of Kelson and others (2002)) was 4 percent. Kelson and others (2002) reported the target value as 1,709,000 $\mathrm{ft}^{3} / \mathrm{d}$ ), although the updated model reported the target value as 1,780,000 $\mathrm{ft}^{3} / \mathrm{d}$.
This close correspondence indicates the suitability of using the updated model without recalibration. Consider, further, that the 4-percent discrepancy is simulated base flow that is less in the updated model than in the original model; this is a conservative finding, in that any error in the shape of the areas contributing recharge is larger rather than smaller.

\section{Summary and Conclusions}

The Sokaogon Chippewa Community (SCC) in Forest County, Wis. has proposed the installation of two new wells near Mole Lake, Wis., that will change the groundwaterpumping regime in the shallow groundwater-flow system. The calculations of areas contributing recharge for the existing and new wells provide an estimate of the source of the water to the wells.

The simulations of the shallow groundwater system in the area of interest used the framework of a previously published model by Kelson and others (2002). In that work, a twodimensional, steady-state, analytic element groundwater-flow model of the regional shallow groundwater-flow system was developed and calibrated using the computer code GFLOW in conjunction with UCODE. The regional model was updated by including more detail to the Rice Lake shoreline and Swamp Creek channel by using topographic maps and adding updated water elevations (measured April 2010) to Rice Lake, Swamp Creek, and Mole Lake.

The updated model was used to calculate 1-, 5-, and 10 -year areas contributing recharge for the expected groundwater-pumping rates of approximately 30 gallons per minute (gal $/ \mathrm{min}$ ) and at higher pumping rates of $70 \mathrm{gal} / \mathrm{min}$ in all three wells. Simulated areas contributing recharge for the SCC wells under both conditions encompassed an area primarily to the north and east of the well locations. The areal extent of the high pumping scenario was greater than that simulated using the proposed pumping rate base scenario and included a potential source of contamination, the septic separator. Neither scenario intersected surface-water features in the area of contribution. 


\section{References Cited}

Freeze, R.A., and Cherry, J.A., 1979, Groundwater: Englewood Cliffs, N.J., Prentice-Hall, 604 p.

Haitjema, H.M., 1995, Analytic element modeling of groundwater flow: San Diego, Calif., Academic Press, 394 p.

Hunt, R.J., 2006, Ground water modeling applications using the analytic element method: Ground Water, v. 44, no. 1, p. 5-14.

Hunt, R.J., Anderson, M.P., and Kelson, V.A., 1998, Improving a complex finite-difference ground water flow model through the use of an analytic element screening model: Ground Water, v. 36, no. 6, p. 1,011-1,017.

Hunt, R.J., Haitjema, H.M., Krohelski, J.T., and Feinstein, D.T., 2003, Simulating ground water-lake interactionsApproaches and insights: Ground Water, v. 41, no. 2, p. 227-237.

Hunt, R.J., and Krohelski, J.T., 1996, The application of an analytic element model to investigate groundwater-lake interactions at Pretty Lake, Wisconsin: Journal of Lake and Reservoir Management, v. 12, no. 4, p. 487-495.

Kelson, V.A., Hunt, R.J., and Haitjema, H.M., 2002, Improving a regional model using reduced complexity and parameter estimation: Ground Water, v. 40, no. 2, p. 132-143, accessed November 12, 2010, at http://onlinelibrary.wiley. com/doi/10.1111/j.1745-6584.2002.tb02498.x/abstract.
Poeter, E.P., and Hill, M.C., 1998, Documentation of UCODE, a computer code for universal inverse modeling: U.S. Geological Survey Water-Resources Investigation Report 98-4080, $116 \mathrm{p}$.

Reilly, T.E., and Pollock, D.W., 1993, Factors affecting areas contributing recharge to wells in shallow aquifers: U.S. Geological Survey Water-Supply Paper 2412, 21 p.

Soller, D.R., and Packard, P.H., 1998, Digital representation of a map showing the thickness and character of Quaternary sediments in the glaciated United States east of the Rocky Mountains: U.S. Geological Survey Digital Data Series 38, CD-ROM.

U.S. Department of Agriculture, 2006, National Agriculture Imagery Program (NAIP) information sheet, accessed October 31, 2008, at http://www.fsa.usda.gov/Internet/FSA_File/ naip_final_2006_updatep.pdf.

Wolf, P.R., and Ghilani, C.D., 2002, Elementary surveyingAn introduction to geomatics (10th ed.): Englewood Cliffs, N.J., Prentice-Hall, 900 p. 

Publishing support provided by the U.S. Geological Survey Science Publishing Network, Columbus Publishing Service Center For more information concerning the research in this report, contact the Director, Wisconsin Water Science Center

U.S. Geological Survey

8505 Research Way

Middleton, Wisconsin 53562

http://wi.water.usgs.gov/ 
